\title{
THE IMPLICATIONS OF DEBT FINANCING ON WORKING CAPITAL MANAGEMENT EFFICIENCY: EVIDENCE FROM MENA EMERGING MARKETS
}

\author{
Luay S. Alrahamneh ${ }^{1,2, *}$, Ei Yet Chu², and Meenchee Hong ${ }^{2}$ \\ 1 School of Business, University of Jordan, Amman, Jordan \\ 2 Graduate School of Business, Universiti Sains Malaysia, Penang, Malaysia
}

\begin{abstract}
This proposed study aims to examine how debt financing affects the working capital management (WCM) efficiency of firms in eight selected MENA countries over the period 20162020. This study discusses different theories of debt financing which include the trade-off theory, the pecking order theory, the market timing theory, and the agency theory (i.e., the agency theory of debt, equity, and free cash flow). Particularly, the study addresses how short-term debt, longterm debt, and total debt influence WCM efficiency. We hypothesize that there are positive relationships between the short-term debt (measured by the current ratio), the long-term debt (measured by the long-term debt to total assets ratio), and the total debt (measured by the total debt to total assets ratio) toward WCM (measured by cash conversion cycle). Firm's specific characteristics such as the firm type, the firm size, firm's sales growth, and tangibility were used as control variables for WCM. To achieve the study objectives, a sample of 718 non-financial listed companies on stock exchanges in countries of Bahrain, Egypt, Jordan, Kuwait, Oman, Qatar, Saudi Arabia, and UAE will be used over the period 2016-2020. Secondary quantitative data will be collected from the annual financial statements of firms. The multiple regression model will be used to test the study hypotheses. This proposed paper originally contributes to the extant literature in several ways. First, there were limited studies of WCM in the MENA context and the current study provided a new insight that has not been investigated before in the MENA region. Thus, it bridges the gap in the literature. However, the majority of extant WCM literature emphasized the relationship between efficient WCM and firms profitability. Moreover, this paper contributes to developing efficient WCM practices and strategies that improve the financial performance of listed companies in the MENA region.
\end{abstract}

ARTICLE HISTORY

Received: $29-8-2020$

Accepted: 2-12-2020

KEYWORDS

Debt Financing,

Working Capital

Management,

MENA

\section{INTRODUCTION}

WCM efficiency is an essential element for firms to deal with during global uncertainties and poor financial conditions (Demir, Esteban, \& Gomez, 2019). According to the extant literature, the importance of WCM stems from many factors. Firstly, WCM affects the firms' profitability, risk, and shareholders' value (Smith, 1980; Le, 2019). Secondly, it is a primary concern during global crisis events. For example, the 2008 global financial crisis has led to a renewed emphasis on WCM (Enqvist, Graham, \& Nikkinen, 2014) and the 2020 COVID-19 pandemic put pressure on a firm's working capital and liquidity issues (Deloitte, 2020). Thirdly, in manufacturing and distributing companies, current assets constitute more than 50\% of total assets (Raheman \& Nasr, 2007). Next, for most companies, there is a significant amount of cash invested in working capital (Deloof, 2003). Lastly, efficient WCM is a crucial instrument for the prosperity and survival of small companies (Pais \& Gama, 2015). Therefore, a great amount of financial managers' time is spent on managing working capital components which are mainly current assets and current liabilities (Bhat, 2008).

The Working Capital is the lifeblood and nerve centre of any business (Mahajan \& Sidhu, 2019). It is defined as the difference between the company's current assets and current liabilities (Brealey, Myers, \& Marcus, 2012; Kovács, Fróna,\& Rózsa, 2020). Efficient management of working capital could mitigate the effect of financial constraints (Ding, Guariglia, \& Knight, 2013). Efficient WCM reduces the idle amount invested in working capital and as a result, minimizes the need for funds to finance working capital (Dhole, Mishra, \& Pal, 2019). An efficient WCM is related to short-term financing decisions and is crucial for balancing the liquidity and profitability of a firm. Firms can adopt a conservative strategy by having excess current assets over current liabilities, which in turn leads to bearing a high cost of liquidity. Alternately, they can follow an aggressive strategy by holding less current assets and this can result in bearing a high cost of illiquidity. Therefore, in both situations, the profitability of the firm can be jeopardized (Panda \& Nanda, 2018).

In the financing of working capital, companies may use the internal sources of funds through free cash flow or the external sources of funds such as short-term and long-term debt. Firms may adopt a less risky working capital financing policy by financing a large proportion of working capital with long-term debt to gain benefits from reductions in the refinancing and interest rate risk. Instead, firms may adopt a riskier working capital financing policy by financing a large proportion of working capital with short-term debt to take the advantages of reductions in the financing costs and better 
credit conditions, thereby alleviate agency costs and signal to the market their positive prospects (Baños-Caballero, García-Teruel, \& Martínez-Solano, 2016).

The bank loans were historically and still a primary source of financing for working capital. The fluctuations in the availability of these loans significantly affect firms' working capital policies which are deemed to be vital to their operations (Chen \& Kieschnick, 2018). Debt financing of a firm is significantly inversely linked with the WCM of a firm, suggesting that with increasing debt to total assets ratio, the firms are assumed to pay more attention to efficient WCM in order to avoid excess capital being invested in accounts receivables and inventories. Therefore, companies with increasing debt to total assets ratio show a lower working capital requirement (Nazir \& Afza, 2009). Debt ratios, in terms of trade credit, short-term debt, and long-term debt, negatively affect firm performance in terms of profitability. As a high debt ratio seems to increase the agency costs and the risk of losing control of the firm, SME owners and managers tend to fund their businesses with equity capital to a fairly high extent (Yazdanfar \& Öhman, 2015).

In MENA region, the non-financial firms have not been proactive in managing their receivables and inventory, and they are adopting an extended payable cycle to manage working capital. There was a net cash opportunity of USD32.7 billion in 2017 trapped across three major areas of working capital (i.e., accounts receivable, inventory, and accounts payable) among three hundred and six listed non-financial firms. The percentage of total working capital to sales for MENA companies increased to 33.7\% in 2017 from 27.4\% in 2013. For instance, in 2017, Jordan, Saudi Arabia, and UAE had the largest working capital per sales percentages (45\%, 43\%, and 35\% respectively) whereas Qatar and Bahrain had the lowest working capital per sales percentages (both, 22\%) (Ernst \& Young, 2018).

A review of the total debt and short-term debt in MENA region in 2016 indicates that they rose by $2.5 \%$ and $12 \%$ respectively. This points out the need for increased investment in working capital required by companies. However, the total net working capital increased by $2 \%$ in 2016 compared to 2015 . The total debt increased by $17 \%$ between 2013 and 2016 (Ernst \& Young, 2017). Debt financing influences the cash holding decisions in MENA region. There is a negative relationship between debt financing and cash holdings which means that MENA firms with the ability to raise funds from external debt financing are capable of generating funds externally, thereby decreasing the need to hold cash (Al-Najjar \& Clark, 2017). The banking markets dominate MENA region's economies with bank deposits to GDP percentage of 80\% in 2015 as compared to the world's average of 50\% (World Bank, 2018). Companies that are using banks to finance working capital in MENA region were reported at 27.3\% of total companies in 2019 (World Bank, 2019).

This paper aims to examine: (1) the relationship between the short-term debt and the WCM efficiency of firms in selected MENA countries, (2) the relationship between the long-term debt and the WCM efficiency of firms in selected MENA countries, and (3) the relationship between the total debt and the WCM efficiency of firms in selected MENA countries. The remainder of this paper is organized as follows: Section 2 provides a literature review of theories and past studies on WCM efficiency, Section 3 discusses the developed hypotheses, Section 4 shows the methodology deployed, and Section 5 presents the conclusion.

\section{LITERATURE REVIEW}

\section{Theories of Debt Financing}

The literature points out different theories trying to explain and understand the capital structure and the debt financing component of capital structure. Modigliani and Miller (1958) argued that in perfect capital markets, the choice between debt financing and equity financing in shaping the capital structure does not significantly affect the firm's value. However, this choice depends on the cost of capital and investment opportunity. Robichek and Myers (1966) argued the relevance of debt policy and the existence of optimal capital structure. Kraus and Litzenberger (1973) posited that optimal financial leverage reflects a trade-off between the tax advantages of debt and bankruptcy penalties. Stiglitz (1974) confirmed the irrelevance of terms of debt in perfect capital markets. Since that, there were many attempts by researchers to explain the debt maturity structure by factors such as taxes, asymmetric information, and agency conflicts in imperfect capital markets (Myers, 1977).

Scott (1976) established a multiperiod model of debt, equity, and a firm valuation that captures the bankruptcy costs and indicates the presence of a unique optimal capital structure. Jensen and Meckling (1976) divided the agency costs into two types: the agency cost of equity and the agency cost of debt. The agency cost of equity is created by the shareholder-managers conflict in interests. However, managers could maximize their personal gains at the expense of shareholders. In contrast, the agency cost of debt (i.e., shareholders-debtholders agency problem) exists when shareholders confiscate the wealth of debtholders in inconvenient investment choices. In 1984, Myers noted in his paper "The Capital Structure Puzzle" that capital structure changes convey information to investors. He contrasted two theories of capital structure: first, the static trade-off theory under which the targeted debt levels can be set when the tax benefits of debt are balanced, at the margin, against the costs of financial distress. Second, the old-fashioned pecking order theory under which the companies prefer internal over external sources of financing, and debt to equity when issuing securities. Companies borrow rather than issue shares when they do not have adequate internal cash flows. Alternatively, companies issue shares when they are overvalued by the market.

Moreover, Jensen (1986) argued that the agency cost of free cash flow happens when excess cash flows are invested in projects with negative net present values. The agency problem between shareholders and managers is exacerbated when a manager uses free cash flow for seeking personal gains at the expense of shareholders. Friend and Lang (1988) documented the importance of agency problems in the determination of the company's capital structure. Myers (1989) 
considered the preliminary organizational theory of capital structure that drops the assumed objective of market value maximization. This theory was the first try to restate Jensen's theory of free cash flow (1986).

Myers (2001) tried to explain how the mix of securities and sources of finance can be used to finance real investments. There is no universal theory in choosing between debt and equity, and no reason to suggest one. Additionally, Myers (2001) mentioned that the free cash flow theory suggests dangerously high levels of debt will improve value, despite the threat of financial distress when a company's operating cash flow significantly exceeds its profitable investment opportunities. The theory of free cash flow is designed for mature firms that are prone to overinvest. Frank and Goyal (2008) posited that the factors of taxation, costs of bankruptcy, adverse selection, and agency costs have all been recommended as main explanations for the companies' use of debt financing.

\section{Past Studies Of Debt Financing}

Nishihara, Sarkar, and Zhang (2019) suggested that with the flexibility of selecting the time and size of the investment, the debt overhang problem (i.e., an equity-maximizing levered company will underinvest relative to a company-value-maximizing company) is of empirical relevance in company investment decisions. Wong (2010) investigated the relationship between investment and financing decisions of owner-managed companies using a real options approach. The results revealed that the debt financing doesn't influence the company's optimal investment intensity. Nevertheless, in general, debt financing does affect the investment timing and in particular, the levered companies invest earlier than the unlevered companies. In contrast, Sarkar (2011) examined the relationship between investment time and investment size with the possibility of debt financing. The findings showed that the investment of companies with the optimal amount of debt is delayed relative to non-debt companies. Moreover, the investment will be higher in size than that of non-debt companies.

Vo (2019) found a negative relationship between financing and investment. This indicates that debt financing is a disciplinary tool to limit corporate investments. Besides, debt financing significantly negatively influences the investment for companies with larger growth opportunities than for companies with smaller growth opportunities. The results have relevant implications in the context of emerging markets. Palombini and Nakamura (2012) suggested that highly leveraged enterprises show more efficient WCM as represented by shorter cash conversion cycles. Dalci and Ozyapici (2018) suggested that the degree of leverage is an important indicator that should be considered by decision-makers in managing working capital. By understanding the level of leverage, they can tighten the working capital policy and decides to adjust the length of cash conversion cycle to improve profitability.

Nasiri and Darabi (2019) concluded that changes in the availability of bank debt significantly affect a number of aspects of a firm's working capital policies, and these effects often differ among bank dependent companies and bank non-dependent companies. Coleman and Baidoo (2020) found that there is an S-curve relationship between debt financing, WCM, and cash holding. Firms that are involved in international activities are largely interested in having borrowing as part of their capital structure than solely operating with owners' capital which might be the case of most domestic firms. The relationship between debt financing, WCM, and cash holding is considered to be non-monotonic which indicates management insight of choosing the right debt management policy to achieve the desired goal.

\section{HYPOTHESES DEVELOPMENT}

The fluctuations in the availability of bank loans have major effects on companies' working capital policies which are considered vital to their day-to-day operations. These effects vary among companies with less or more dependence on bank loans. Companies with more dependence on bank loans have excess cash and depend more on short-term debts (Chen \& Kieschnick, 2018).

Long-term debt has a positive impact on the company's liquidity as it is a source of funds that could enhance liquidity (Masri \& Abdulla, 2018). In common-law systems, companies tend to have lower levels of working capital, less internal sourcing of working capital from retained profits, and more external sourcing from banks (Troilo, Walkup, Abe, \& Lee, 2019). WCM is considered a primary interest to companies with less access to finance and to companies that seek to expand their investments during periods of economic recovery (Le, 2019). Therefore, we hypothesized that:

$\mathbf{H}_{1}$ : There is a positive relationship between the short-term debt and WCM of firms in selected MENA countries.

$\mathbf{H}_{2}$ : There is a positive relationship between the long-term debt and WCM of firms in selected MENA countries.

H3: There is a positive relationship between the total debt and WCM of firms in selected MENA countries.

\section{METHODOLOGY}

\section{Data Collection and Measurement of Variables}

The 718 non-financial companies listed on stock exchanges in MENA countries will be used as a study sample over the period 2016-2020. The chosen period will let us obtain representative results as they reflect the most recent events. The secondary data will be collected from stock exchange websites in MENA countries. The dependent variable which is the WCM is proxied by the cash conversion cycle, in which the variance is explained by the independent variables (namely short-term debt, the long-term debt, and the total debt). The short-term debt (STD) will be measured by the 
current ratio, the long-term debt (LTD) will be measured by the ratio of long-term debt to total assets, and the total debt (TD) will be proxied by the ratio of total debt to total assets. Moreover, with respect to the control variables, the firm type (FT) is a dummy variable that takes 1 if the firm is from the industrial sector and 0 otherwise, the firm size (FS) is proxied by natural logarithm of total assets, the firm sales growth (SG) is proxied by annual change in sales, the tangibility (TAN) is measured by net property, plant, and equipment to total assets.

Model specification and Methods of Analysis

\section{Model (1):}

$$
W C M_{i t}=\alpha_{0 i t}+\beta_{1 i t} S T D_{i t}+\beta_{2 i t} F T_{i t}+\beta_{3 i t} F S_{i t}+\beta_{4 i t} S G_{i t}+\beta_{5 i t} T A N_{i t}+\varepsilon_{i t}
$$

Model one is used to achieve the first objective which is examining the relationships between the STD and WCM of firms in selected MENA countries, where multiple regression analysis is used to test Hypothesis one (H1).

Model (2):

$$
W C M_{i t}=\alpha_{0 i t}+\beta_{1 i t} L T D_{i t}+\beta_{2 i t} F T_{i t}+\beta_{3 i t} F S_{i t}+\beta_{4 i t} S G_{i t}+\beta_{5 i t} T A N_{i t}+\varepsilon_{i t}
$$

Model two is used to achieve the second objective which is examining the relationships between the LTD and WCM of firms in selected MENA countries, where multiple regression analysis is used to test Hypothesis two (H2).

Model (3):

$$
W C M_{i t}=\alpha_{0 i t}+\beta_{1 i t} T D_{i t}+\beta_{2 i t} F T_{i t}+\beta_{3 i t} F S_{i t}+\beta_{4 i t} S G_{i t}+\beta_{5 i t} T A N_{i t}+\varepsilon_{i t}
$$

Model three is used to achieve the third objective which is examining the relationships between the TD and WCM of firms in selected MENA countries, where multiple regression analysis is used to test Hypothesis three (H3).

\section{CONCLUSION}

This proposed study examines the relationship between debt financing and the WCM efficiency of non-financial firms in selected MENA countries over the period 2016-2020. More specifically, it addresses the relationship between factors such as short-term debt, long-term debt, and total debt toward WCM efficiency. The study started with an introductory section about the WCM efficiency followed by a literature review of theories which include the trade-off theory, the pecking order theory, the market timing theory, and the agency theory; and past studies of debt financing. The study also presents the hypotheses developed and the methodology deployed in terms of data collection, measurement of variables, model specifications, and methods of analysis ending with this conclusion.

\section{REFERENCES}

Al-Najjar, B., \& Clark, E. (2017). Corporate governance and cash holdings in MENA: Evidence from internal and external governance practices. Research in International Business and Finance, 39, 1-12.

Baños-Caballero, S., García-Teruel, P. J., \& Martínez-Solano, P. (2016). Financing of working capital requirement, financial flexibility and SME performance. Journal of Business Economics and Management, 17(6), 1189-1204.

Bhat, S. (2008). Financial management: Principles and practice. Excel Books India.

Brealey, R. A., Myers, S. C., \& Marcus, A. J. (2012). Fundamentals of corporate finance. McGraw-Hill/Irwin,.

Chen, C., \& Kieschnick, R. (2018). Bank credit and corporate working capital management. Journal of Corporate Finance, 48, 579596. https://doi.org/10.1016/j.jcorpfin.2017.12.013

Coleman, M., \& Baidoo, J. M. (2020). The Interaction of Financial Leverage and Firm's Operational Efficiency. Business and Economic Research, 10(1), 235-250.

Dalci, I., \& Ozyapici, H. (2018). Working capital management policy in health care: The effect of leverage. Health Policy, 122(11), $1266-1272$.

Deloitte, 2020. Addressing the financial impact of COVID-19: Credit solutions for companies with urgent cash needs. Available online: https://www2.deloitte.com/content/dam/Deloitte/global/Documents/About-Deloitte/RESPOND-Cash-Flow-Managementliquidity-constraints-COVID19.pdf

Deloof, M. (2003). Does working capital management affect profitability of Belgian firms? Journal of Business Finance and Accounting, 30(3-4), 573-587. https://doi.org/10.1111/1468-5957.00008

Demir, E., Díez-esteban, J. M., \& García-Gómez, C. D. (2019). The impact of geopolitical risks on cash holdings of hospitality companies : Evidence from emerging countries. Journal of Hospitality and Tourism Management, 39, 166-174.

Dhole, S., Mishra, S., \& Pal, A. M. (2019). Efficient working capital management, financial constraints and firm value: A text-based analysis. Pacific Basin Finance Journal, 58, 101212. https://doi.org/10.1016/j.pacfin.2019.101212

Ding, S., Guariglia, A., \& Knight, J. (2013). Investment and financing constraints in China: Does working capital management make a difference? Journal of Banking and Finance, 37(5), 1490-1507. https://doi.org/10.1016/j.jbankfin.2012.03.025

Enqvist, J., Graham, M., \& Nikkinen, J. (2014). Research in International Business and Finance The impact of working capital management on firm profitability in different business cycles : Evidence from Finland. Research in International Business and Finance, 32, 36-49. https://doi.org/10.1016/j.ribaf.2014.03.005 
Ernst \& Young, 2017. All tied up MENA - Working capital management report 2017. Available online: https://www.ey.com/Publication/vwLUAssets/ey-all-tied-up-mena-working-capital-management-report-2017/\%24FILE/eyall-tied-up-mena-working-capital-management-report-2017.pdf

Ernst \& Young, 2018. All tied up MENA - Working capital management report 2018. Available Online: https://www.de.ey.com/Publication/vwLUAssets/ey-all-tied-up-mena-working-capital-management-report-2018/\%24FILE/eyall-tied-up-mena-working-capital-management-report-2018.pdf

Frank, M. Z., \& Goyal, V. K. (2008). Trade-off and pecking order theories of debt. In Handbook of empirical corporate finance (pp. 135-202). Elsevier.

Friend, I., \& Lang, L. H. (1988). An empirical test of the impact of managerial self-interest on corporate capital structure. the Journal of Finance, 43(2), 271-281.

Jensen, M. C. (1986). Agency Costs of Free Cash Flow, Corporate Finance, and Takeovers. The American Economic Review, 76(2), 323-329.

Jensen, M. C., \& Meckling, W. H. (1976). THEORY OF THE FIRM: MANAGERIAL BEHAVIOR, AGENCY COSTS AND OWNERSHIP STRUCTURE. Journal of Financial Economics, 3, 305-360.

Kovács, S., Fróna, D., \& Rózsa, A. (2020). Analysing The Situation Of Agricultural Enterprises In Liquidation By Means Of Bankruptcy Prediction Models. SEA-Practical Application of Science, (22), 23-31.

Kraus, A., \& Litzenberger, R. H. (1973). A state-preference model of optimal financial leverage. The journal of finance, 28(4), 911922.

Le, B. (2019). Working capital management and firm's valuation, profitability and risk: Evidence from a developing market. International Journal of Managerial Finance, 15(2), 191-204.

Mahajan, D., \& Sidhu, A. (2019). Source of Finance Resorted to, Cost Involved in Financing and Financing Decisions Taken by MSMEs: An Insight into Sports Goods Industry of Punjab. SEDME (Small Enterprises Development, Management \& Extension Journal), 46(2), 57-69.

Masri, H., \& Abdulla, Y. (2018). A multiple objective stochastic programming model for working capital management. Technological Forecasting and Social Change, 131, 141-146.

Modigliani, F., \& Miller, M. H. (1958). The cost of capital, corporation finance and the theory of investment. The American economic review, 48(3), 261-297.

Myers, S. C. (1977). Determinants of corporate borrowing. Journal of financial economics, 5(2), 147-175.

Myers, S. C. (1984). Capital structure puzzle (No. w1393). National Bureau of Economic Research.

Myers, S. C. (1989). Still searching for optimal capital structure. Are the distinctions between debt and equity disappearing, 80-95.

Myers, S. C. (2001). Capital structure. Journal of Economic perspectives, 15(2), 81-102.

Nasiri, Z., \& Darabi, R. (2019). The Role of the Availability of Bank Credit in Corporate Working Capital Management.

Nazir, M. S., \& Afza, T. (2009). Working Capital Requirements and the Determining Factors in Pakistan. IUP Journal of Applied Finance, 15(4), 28-38. http://search.proquest.com/docview/196843853

Nishihara, M., Sarkar, S., \& Zhang, C. (2019). Agency cost of debt overhang with optimal investment timing and size. Journal of Business Finance and Accounting, 46(5-6), 784-809.

Pais, M. A., \& Gama, P. M. (2015). Working capital management and SMEs profitability: Portuguese evidence. International journal of managerial finance.

Palombini, N. V. N., \& Nakamura, W. T. (2012). Key factors in working capital management in the Brazilian market. Revista de Administração de Empresas, 52(1), 55-69.

Panda AK, Nanda S (2018) Working capital financing andcorporate profitability of Indian manufacturing firms. Management Decision 56 (2): 441-457. https://doi.org/10.1108/MD-07-2017-0698.

Raheman, A., \& Nasr, M. (2007). Working Capital Management And Profitability - Case Of Pakistani Firms. International Review Of Business Research Papers, 3(1), 279-300. https://doi.org/10.1016/j.ribaf.2014.03.005

Robichek, A. A., \& Myers, S. C. (1966). Problems in the theory of optimal capital structure. Journal of Financial and Quantitative Analysis, 1(2), 1-35.

Sarkar, S. (2011). Optimal size, optimal timing and optimal financing of an investment. Journal of Macroeconomics, 33(4), 681-689.

Scott Jr, J. H. (1976). A theory of optimal capital structure. The Bell Journal of Economics, 33-54.

Smith K (1980), Profitability versus Liquidity Tradeoffs in Working Capital Management, in Readings on the Management of Working Capital, West Publishing Company, New York

Stiglitz, J. E. (1974). On the irrelevance of corporate financial policy. The American Economic Review, 64(6), 851-866.

Troilo, M., Walkup, B. R., Abe, M., \& Lee, S. (2019). Legal systems and the financing of working capital. International Review of Economics \& Finance, 64, 641-656.

Vo, X. V. (2019). Leverage and corporate investment-Evidence from Vietnam. Finance Research Letters, 28, 1-5.

Wong, K. P. (2010). On the neutrality of debt in investment intensity. Annals of Finance, 6(3), 335-356.

World Bank (2018), World Bank Open Data (database, accessed on 01 January 2019). Website: https://data.worldbank.org/

World Bank. 2019. Global Financial Development Report 2019/2020: Bank Regulation and Supervision a Decade after the Global Financial Crisis. Washington, DC: World Bank. doi:10.1596/978-1-4648-1447-1. License: Creative Commons Attribution CC BY 3.0 IGO

Yazdanfar, D., \& Öhman, P. (2015). Debt financing and firm performance: an empirical study based on Swedish data. The Journal of Risk Finance, 16(1). 


\section{ACKNOWLEDGEMENT}

The authors would like to thank the editor and anonymous refrees who kindly reviewed the earlier version of this manuscript and provided valuable suggestions and comments.

\section{DECLARATION CONFLICT OF INTEREST}

The authors declare that there is no conflict of interests.

\section{AUTHORS' BIOGRAPHY}

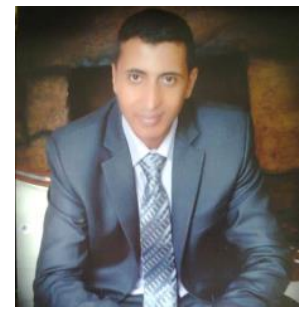

Luay S. Alrahamneh is a full-time lecturer working at School of Business, University of Jordan. His current research interests include working capital management issues.

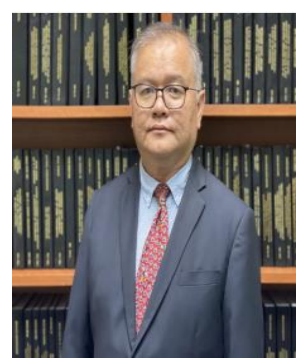

Dr Chu Ei Yet is a senior lecturer at the Graduate School of Business, Universiti Sains Malaysia. His teaching and research interests focus on corporate finance and corporate governance.



Meenchee Hong is a senior lecturer at the Graduate School of Business, Universiti Sains Malaysia. She obtained her PhD (Economics) at James Cook University, Australia. Besides teaching, she is also active in research, particularly in the area of industry economics, international trade, and sustainability related issues. 